\title{
The Impact Of Customer Satisfaction On Chief Marketing Officer's Compensation
}

Heiwai Lee, Ph.D., University of Michigan, Dearborn, USA

Crystal J. Scott, Ph.D., University of Michigan, Dearborn, USA

\begin{abstract}
As an intangible marketing asset, customer satisfaction is rarely apparent on financial statements. The contribution of customer satisfaction on firm financial performance is well documented, but it is unclear whether this positive link is reflected in executive compensation. Besides, executives are often compensated for short-term financial results but the outcome of marketing actions is rarely captured in a short horizon. This research seeks to determine if the compensation of Chief Marketing Officer's (CMO), who is primarily responsible for marketing outcome, is impacted by customer satisfaction. We find that customer satisfaction has a significantly positive impact on the total cash compensation of CMO and its cash and bonus components when controlling for firm performance, firm size, and innovation. Overall, our results support the inclusion of nonfinancial performance measures, specifically customer satisfaction, in designing senior marketing executive compensation packages.
\end{abstract}

Keywords: Customer Satisfaction and Chief Marketing Officer Compensation

\section{INTRODUCTION}

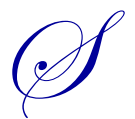

imilar to other marketing assets such as brand equity and customer/channel relationships, the intangible nature of customer satisfaction is difficult to quantify and not readily apparent on financial statements. The marketing literature, however, documents extensive evidence on positive associations of customer satisfaction with customers' loyalty, receptivity to cross-selling efforts, advertising efficiency, and word-of-mouth that favorably impact financial performance of the firm (Fornell, et al., 1996; Srivastava, et al., 1998; Luo and Homburg, 2007). Furthermore, recent research shows that customer satisfaction has a favorable effect on cash flows and hence shareholder value as well as analysts' recommendation rating of a firm (Anderson, et al., 2004; Gruca and Rego, 2005; Fornell, et al., 2006; Luo, et al., 2010).

Most executive compensation research that focuses on CEO compensation uses accounting and valuation based performance measures to design and explain compensation packages for senior executives (Jensen and Murphy, 1990; Devers, et al. 2007). However, empirical findings on the associations between executive compensation and such performance measures have been mixed. For instance, increases in CEO compensation for every $\$ 1,000$ increase in shareholder value range from $\$ 3.25$ to $\$ 14.52$. Tosi, et al. (2000) report that accounting based performance measures account for less than 5\% of the variation in CEO compensation. These findings suggest a possible role of nonfinancial decisions of executives in explaining their compensation (O'Connell and O'Sullivan, 2010; Goergen and Renneboog, 2011). Besides, Mizik and Jacobson (2007) suggest that executives who focus solely on accounting measures, which are backward-looking, can be susceptible to self-serving myopic decision making that may conflict with shareholders' interests. They propose that a broader set of performance metrics should be used for incentivizing executives, "managers will be less likely to manage firm resources myopically if they are held accountable and are evaluated based not only on the accounting earnings measures, but also based on the health of the marketing assets (brand equity, customer satisfaction, etc.)" (p. 376).

Recently, Luo and Homburg (2007) call for research to show if and how marketing metrics, such as customer satisfaction, incentivize senior executives. In this study, we answer their call by examining the possible role of intangible marketing metrics, specifically customer satisfaction, on executive compensation, i.e., whether 
executives are compensated for investing resources in less tangible marketing activities. As a complement to O'Connell and Sullivan (2010) that examines the role of customer satisfaction in explaining CEO bonuses, we seek to determine if the Chief Marketing Officer's (CMO) compensation is impacted by this important, but intangible marketing asset. Our contention is that although the CEO is held accountable for overall firm performance, marketing executives are most directly responsible for the outcomes of investments in marketing assets. Hence, we believe that customer satisfaction, being a major measure of successful marketing decisions, would play a material role in determining the compensation of marketing executives. In addition, our research also sheds light on whether the positive link between customer satisfaction and financial performance documented in the literature is reflected in executive compensation. We postulate that a financial incentive in the compensation package may persuade executives to invest in intangible marketing assets that could enhance firm performance.

Our study also adds to the scant research on marketing executives. Prior studies focus on the drivers of the presence of marketing executives in the top management team (TMT) and their impacts on firm performance. Little is known about the compensation of the $\mathrm{CMO}$ and if their pay scheme is influenced by the marketing actions for which they are responsible. However, Homburg, et al. (1999) report that the marketing group has the most influence on customer satisfaction compared to other functional groups (e.g., R\&D, finance, etc). Hence, our study contributes to both the executive compensation literature regarding the possible role of intangible marketing assets in explaining compensation packages, and the marketing literature regarding the rising role of marketing executives in the top management team.

To summarize, we find that customer satisfaction has a positive and significant impact on the marketing executive's total current compensation and its salary and bonus components. This finding indicates that intangible marketing assets not only enhance the financial performance of a firm, but also impact CMO compensation. Our findings echo the call for including nonfinancial performance measures in the design of executive compensation packages. Being the first study on the relation between compensation and decisions of senior marketing executives, our research contributes to our understanding on the presence of $\mathrm{CMO}$ in the top management team. Our findings have practical implications for organizations designing compensation packages for the top management team. Along with prior empirical evidence on positive impacts of customer satisfaction on financial performance and valuation of firms documented in the literature, our findings incentivize marketing executives and other TMT members to consider allocating resources to this intangible but important marketing asset (i.e. customer satisfaction).

In the next section, we review the literature and develop hypotheses on the impacts of customer satisfaction, firm and branding strategies, as well as the experiences of marketing executives on their compensation. In Section III, we discuss our sample and our methodology. We report and discuss our findings in Section IV, and conclude our paper in Section V.

\section{HYPOTHESES}

The position of CMO has been known as the "hot seat" on the top management team. The average CMO tenure is about 27 months compared to over 40 months for other TMT members. The short tenure of marketing executives is likely due to an inherent conflict in their responsibilities and how their performance is evaluated. Since the work of CMOs is mostly long term, centering on brand and relationship building and increasing customer loyalty, the performance of these long-term and often intangible marketing assets, like customer satisfaction, should be a determinant of CMO compensation (Mizik and Jacobson, 2007). However, little is known about the use of intangible marketing assets in executive compensation plans and even less is known about CMO compensation specifically.

There are a number of reasons for using forward-looking performance measures such as customer satisfaction as the nonfinancial incentive in designing executive compensation plans (Dikolli and Vaysman, 2006). For many firms, customer satisfaction has become a strategic priority across the organization. From a customer standpoint, we see increased loyalty, lower defection rates, and a willingness to pay more from satisfied customers. Prior research has also shown that customer satisfaction positively affects cash flows, enhancing shareholder value and reducing volatility. More recently, Luo, et al. (2010) find that customer satisfaction leads to improved analyst stock recommendations with lower dispersion among those recommendations. 
In a study by the CMO Council of over 300 Chief Marketing Officers, customer satisfaction was selected as one of the most important marketing metrics because of its link to economic and marketing outcomes (Stewart 2009). Given the extensive empirical evidence on the positive impact of customer satisfaction on firm performance, we expect customer satisfaction to positively impact executive compensation, especially senior marketing executives who are primarily responsible for its outcome. Thus, we propose the following:

H1: Customer satisfaction will have a positive and significant relation to CMO compensation.

\section{Branding Strategy}

Branding strategies range from a single brand to a house of brands maintained by a firm. We adopt Laforet and Saunders's (1994) three-category scheme, which is based on the use of the company's name in the product and service brand names, in our analysis. The three categories of branding strategies are: (1) corporate branding, (2) house of brands, and (3) mixed branding. The corporate branding strategy uses only the company's name on products and services, allowing the firm to build and leverage the reputation of a single brand name (e.g., HewlettPackard, McKinsey and Company). The advantage of a single corporate brand is the economies of scale, such as lower costs in advertising and building brand equity.

A firm using the house of brands strategy does not use the company name for endorsing products and services and hence may have increased marketing expenses related to brand building. Examples of this strategy include Ivory Soap and Huggies diapers, both are products of Procter and Gamble (P\&G). One benefit of the house of brands strategy is that firms introducing new products will not harm the company name with potential product failures. The mixed brand strategy combines both the corporate branding strategy and the house of brands strategy in which a company will use both the corporate and brand name for certain products (e.g. Kellogg's Corn Flakes and Kellogg's Raisin Brand). With this strategy both the company and product name are prominent in the branding.

Firms with a corporate branding strategy are likely to be very protective of the brand name because it is a critical asset to the company given its appearance on every product and service. Additionally, failure of any one of the company's products can damage the firm's reputation. Nath and Mahajan (2008) find that firms that adopt the corporate branding strategy are more likely to have a CMO than firms that do not. This could be because firms expect the CMO to be chiefly responsible for maintaining and building the reputation of the brand. We postulate that firms with a corporate branding strategy will offer a higher compensation for greater responsibilities to their CMOs than firms that adopt other branding strategies. Thus we propose the following:

H2: Corporate branding strategy will have a positive and significant impact on CMO compensation.

\section{Firm Strategy}

Recent studies suggest that higher executive compensation is associated with firms that pursue a strategy of innovation and growth than firms that adopt a conservative approach of maintaining their market share (Balkin, et al. 2000; Montemayor, 1996). More specifically, Nath and Mahajan (2008) determine that the likelihood of having a CMO position in a firm is positively related to firms pursuing a strategy that emphasizes differentiation and innovation. These firms invest in advertising intensity, brand equity, and are concerned with premium pricing. Firms making these types of investments are more likely to have a CMO to oversee the marketing initiatives associated with innovation and bringing new products to market. Such initiatives will require close monitoring of customer relationships and satisfaction. Given the findings of Balsam, et al. (2011) that firms pursuing a differentiation strategy place less weight on accounting based performance measures, we expect such firms placing more emphasis on the intangible nonfinancial measures in determining the CMO's performance and compensation. Specifically, we expect the greater the investment in innovation the higher the CMO compensation.

H3: Innovation will have a significant and positive relationship to CMO compensation. 


\section{Role Specific Experience}

Role-specific experience refers to an individual's professional experience in a functional area. We define role-specific experience for marketing executives as the number of years the executive has spent in the field of marketing. CMOs that have spent the majority of their career in marketing may have a different perspective on their job tasks and marketing decisions than marketing executives that have less marketing experience. Boyd, et al. (2010) find that role-specific experience helps CMOs offset the effects that powerful customers have on their decision making regarding firm resources. Prior experience in marketing may be viewed favorably by a firm hiring senior marketing executives. For this reason we suggest the following:

H4: Role-specific experience will have a positive and significant effect on CMO compensation.

\section{METHODOLOGY}

\section{Sample}

We first scanned the ExecuComp database for U.S. firms that have marketing executives included in the top management team (TMT) for compensation data over the period of 1991-2010. The ExecuComp database contains comprehensive compensation data for highest paid executives and directors of U.S. firms listed on the Standard \& Poor's 1500 index. We follow Nath and Mahajan's (2008) identification of senior marketing executives as those TMT members with the following titles: CMO, VP of marketing, Executive VP of marketing, and Senior VP of marketing. There are 68 companies with highly compensated marketing executives in our initial sample. We then cross-matched with the American Customer Satisfaction Index (ASCI) database for customer satisfaction data over the sample period. The ASCI data is provided by the National Quality Research Center at The University of Michigan and has been used extensively in the literature to measure customer satisfaction (Fornell, et al., 1996; Gruca and Rego, 2005; Luo, et al., 2010). ASCI is measured annually on a 0 to 100 scale over the period of 1994 to 2010. It measures customer satisfaction for over 40 industries representing $45 \%$ of the GDP. Lastly, we checked the COMPUSTAT database for financial data needed for our analysis.

Our final sample is composed of 31 companies and 144 observations that meet the stringent selection criteria that require available data on the moderate ACSI sample of approximately 225 firms, the ExecuComp database and the COMPUSTAT database. We note that other empirical studies that involve customer satisfaction rating and COMPUSTAT data have similar challenge of small sample size (Boyd and Chandy Jr., 2010; Nath and Mahajan, 2008, 2011). Given the unique focus of this study that contributes to our understanding of the role of key marketing function in the design of the compensation of marketing executives, we deem the topic is worthy of exploration despite the inherent limitations on the sample size.

Dependent Variable. We use three compensation measures for the dependent variable: total current compensation, salary and bonus, respectively. The compensation data were retrieved from ExecuComp for the period 1991 - 2010, and are adjusted to Y2000 dollars in order to isolate the inflation effect. Following O'Connell and O'Sullivan (2010), we also excluded observations that have more than one marketing executive for the same company in any given year because the compensation amount may not be for the full year that could lead to bias results.

Independent Variables. In addition to the customer satisfaction (Satisfaction) variable that is measured with the ASCI score as the key marketing asset in our analysis, we also examine selected marketing variables that could impact the performance and hence the compensation of senior marketing executives. The branding strategy (Branding) for the firm was coded as a ' 1 ' for a corporate branding strategy and ' 0 ' for a house of brands or mixed branding strategy. We manually coded the strategies using information from company 10K-s and company websites with input from an outside field expert. We use innovation as a measure of firm strategy and define it as the ratio of R\&D spending to sales (RDSales) for the same year of the compensation data. The annual data for R\&D spending and sales were extracted from the COMPUSTAT database. We define role-specific experience (RoleSpecific) as the years of marketing experience possessed by the executive. This information was pulled from various biographical sources such as company websites, annual reports, and online articles. 
Control variables. We control for the influence of a number of variables known for impacting executive compensation, including firm specific experience of marketing executives, the size and performance of the firm. Firm-specific experience is the length of time an individual has been with his or her current company (FirmSpecific). Prior research has shown that outsider CEOs were paid more than their predecessors but this relationship did not hold for internally promoted CEOs (Hambrick and Finkelstein, 1995). Such wage compression may occur when an internally promoted CMO is less compensated than a CMO hired from outside the firm. Hence, firm-specific experience of marketing executives is expected to have a negative impact on their compensation.

Tosi, et al. (2000) find that firm size accounts for $40 \%$ of the variation in CEO compensation, suggesting that firm size could also explain CMO compensation. Here, we include firm size (lnNumEmpl) as a control variable, which is defined as the logarithm of the number of employees for the same year when the compensation data were used, as reported in COMPUSTAT. As profitability has a positive impact on executive compensation (Devers, et al., 2007), we control for the possible secondary effect of customer satisfaction on CMO compensation via its positive association with firm performance by including prior year's return on assets (ROA) that we extracted data from COMPUSTAT in our analysis. compensation:

Next, we estimate three cross-sectional regressions to examine customer satisfaction on CMO

$$
\begin{aligned}
& \text { lnComp }_{\mathrm{i}, \mathrm{t}}=\beta_{\mathrm{o}}+\beta_{1} \text { Satisfaction }_{\mathrm{i}, \mathrm{t}}+\beta_{2} \text { Branding }_{\mathrm{i}, \mathrm{t}}+\beta_{3} \text { RDSales }_{\mathrm{i}, \mathrm{t}}+\beta_{4} \text { RoleSpecific }_{\mathrm{i}, \mathrm{t}} \\
& +\mathrm{B}_{5} \text { FirmSpecific }_{\mathrm{i}, \mathrm{t}}+\beta_{6} \operatorname{lnNumEmpl}_{\mathrm{i}, \mathrm{t}}+\beta_{7} \mathrm{ROA}_{\mathrm{i}, \mathrm{t}-1}+\mathrm{e}_{\mathrm{i}, \mathrm{t}} \text {. } \\
& \operatorname{lnSalary}_{i, t}=\beta_{o}+\beta_{1} \text { Satisfaction }_{i, t}+\beta_{2} \text { Branding }_{i, t}+\beta_{3} \text { RDSales }_{i, t}+\beta_{4} \text { RoleSpecific }_{i, t} \\
& +\mathrm{B}_{5} \text { FirmSpecific }_{\mathrm{i}, \mathrm{t}}+\beta_{6} \operatorname{lnNumEmpl}_{\mathrm{i}, \mathrm{t}}+\beta_{7} \mathrm{ROA}_{\mathrm{i}, \mathrm{t}-1}+\mathrm{e}_{\mathrm{i}, \mathrm{t}} \text {. } \\
& \text { lnBonus }_{\mathrm{i}, \mathrm{t}}=\beta_{\mathrm{o}}+\beta_{1} \text { Satisfaction }_{\mathrm{i}, \mathrm{t}}+\beta_{2} \text { Branding }_{\mathrm{i}, \mathrm{t}}+\beta_{3} \text { RDSales }_{\mathrm{i}, \mathrm{t}}+\beta_{4} \text { RoleSpecific }_{\mathrm{i}, \mathrm{t}} \\
& +\mathrm{B}_{5} \text { FirmSpecific }_{\mathrm{i}, \mathrm{t}}+\beta_{6} \operatorname{lnNumEmpl}_{\mathrm{i}, \mathrm{t}}+\beta_{7} \mathrm{ROA}_{\mathrm{i}, \mathrm{t}-1}+\mathrm{e}_{\mathrm{i}, \mathrm{t}} \text {. }
\end{aligned}
$$

We use the logarithm of the total current compensation (lnComp), the salary component (lnSalary) and the bonus component (lnBonus), respectively, for the dependent variable in the regressions. For the Satisfaction variable, we use a 3-year rolling average ASCI score to account for possible delayed effects of the marketing outcome on the compensation measures (Srinivasan and Hanssens 2009).

\section{RESULTS}

Table 1 reports the descriptive statistics on the compensation and experiences of marketing executives, as well as selected characteristics of sample firms. The average (median) CMO total current compensation is $\$ 567,709$ $(\$ 494,220)$ with a range of $\$ 139,400$ to $\$ 1,791,730$, while the average (median) cash salary is $\$ 366,219(\$ 349,520)$, with a range of $\$ 120,270$ to $\$ 991,730$. Among marketing executives that have a bonus, the average (median) CMO bonus is $\$ 201,490(\$ 106,850)$ over the range of $\$ 0$ to $\$ 950,000$, while approximately one-fourth of the CMOs do not have a bonus. Marketing executives in our sample have an average of approximately 20 years of experience in the field with roughly half of their experiences (approximately 11 years) associated with the same firm. The most experienced marketing executive in our sample accumulates his/her 36 years of experiences with Apple, Inc.

The average (median) ASCI satisfaction rating is 76.72 (79), based on a scale of 0 to 100 , with a minimum of 61 and a maximum of 87. In comparison, the national average ASCI score has ranged from a high of 87 in 2009 to a low of 61 in 2006, with an average national ASCI score of 75.6 in 2010. Over $60 \%$ of sample firms adopt the corporate branding strategy, and invest an average (median) of 3\% (1\%) of their annual sales in R\&D expenditure. The average (median) ROA of sample firm is $5.597 \%$ (6.80\%) with a wide range of $-24.69 \%$ to $21.06 \%$. The average firm size is 42,096 employees. 
Table 1: Descriptive statistics

\begin{tabular}{|c|c|c|c|c|c|c|c|c|c|c|}
\hline & $\begin{array}{c}\text { Total } \\
\text { Current } \\
\text { Compensation } \\
(\$ 1,000)\end{array}$ & $\begin{array}{c}\text { Salary } \\
(\$ 1,000)\end{array}$ & $\begin{array}{l}\text { Bonus } \\
(\$ 1,000)\end{array}$ & $\begin{array}{c}\text { Satisfaction } \\
\text { Rating }\end{array}$ & Branding & $\mathrm{Rd} /$ Sales & $\begin{array}{c}\text { Role } \\
\text { Specific } \\
\text { Experience }\end{array}$ & $\begin{array}{c}\text { Firm } \\
\text { Specific } \\
\text { Experience }\end{array}$ & $\begin{array}{c}\text { Firm Size } \\
\text { (\# employees } \\
\text { in } 1,000)\end{array}$ & ROA \\
\hline Mean & 567.71 & 366.22 & 201.49 & 76.72 & 0.61 & 0.03 & 20.32 & 10.83 & 42.09 & 5.97 \\
\hline Median & 494.22 & 349.52 & 106.85 & 79.00 & 1.00 & 0.01 & 21.00 & 8.00 & 25.25 & 6.80 \\
\hline Std. Deviation & 347.57 & 172.05 & 245.85 & 7.16 & 0.49 & 0.05 & 8.44 & 9.84 & 68.22 & 6.93 \\
\hline Variance & 120804.32 & 29601.71 & 60444.34 & 51.28 & 0.24 & 0.00 & 71.20 & 96.92 & 4653.40 & 48.07 \\
\hline Skewness & 1.34 & 0.96 & 1.41 & -0.41 & -0.44 & 3.81 & -0.09 & 1.37 & 3.82 & -1.56 \\
\hline Kurtosis & 1.90 & 1.10 & 1.09 & -1.31 & -1.84 & 22.14 & -0.69 & 0.87 & 16.39 & 4.54 \\
\hline Minimum & 139.40 & 120.27 & 0.00 & 61.00 & 0.00 & 0.00 & 1.00 & 0.70 & 0.52 & -24.69 \\
\hline Maximum & 1791.73 & 991.73 & 950.00 & 87.00 & 1.00 & 0.36 & 36.00 & 36.00 & 399.41 & 21.06 \\
\hline Percentiles 25 & 304.13 & 226.73 & 0.00 & 69.50 & 0.00 & 0.00 & 13.25 & 4.00 & 6.05 & 3.73 \\
\hline 50 & 494.22 & 349.52 & 106.85 & 79.00 & 1.00 & 0.01 & 21.00 & 8.00 & 25.25 & 6.80 \\
\hline 75 & 745.77 & 455.55 & 300.00 & 83.00 & 1.00 & 0.04 & 27.00 & 15.25 & 44.00 & 9.63 \\
\hline
\end{tabular}

The correlation coefficients reported in Table 2 show that all three of our dependent variables are positively correlated to our key explanatory variable - customer satisfaction rating. Consistent with other executive compensation studies, we also observe that firm size is highly correlated with the three compensation variables in our sample. This suggests that marketing executives from larger firms receive greater compensation than their counterparts from smaller firms. Firm size is negatively correlated with the R\&D to sales ratio that might be driven by the high correlation between the sales level and our firm size measure. It is interesting to note that larger firms tend to adopt the corporate branding strategy. Not surprisingly, we also observe a high correlation between firm specific experience and role specific experience. Though the correlation matrix does not suggest serious multicollinearity issues among the explanatory variables, we further examine the possible multicollinearity problem in our regression analysis given the instances of seemingly high correlations among selected variables discussed above.

Table 2: Correlations Matrix

\begin{tabular}{|c|c|c|c|c|c|c|c|c|c|c|}
\hline & (1) & (2) & (3) & (4) & (5) & (6) & (7) & (8) & (9) & (10) \\
\hline (1) Total Current Compensation & 1 & & & & & & & & & \\
\hline (2) Salary & $\begin{array}{r}0.80 \\
+(0.00)\end{array}$ & 1 & & & & & & & & \\
\hline (3) Bonus & $\begin{array}{c}0.87 \\
(0.00)\end{array}$ & $\begin{array}{c}0.59 \\
(0.00)\end{array}$ & 1 & & & & & & & \\
\hline (4) Satisfaction Rating & $\begin{array}{r}0.56 \\
(0.00)\end{array}$ & $\begin{array}{r}0.45 \\
(0.00)\end{array}$ & $\begin{array}{c}0.46 \\
(0.00)\end{array}$ & 1 & & & & & & \\
\hline (5) Branding & $\begin{array}{r}0.20 \\
(0.02)\end{array}$ & $\begin{array}{r}0.21 \\
(0.02)\end{array}$ & $\begin{array}{r}0.26 \\
-\quad(0.01)\end{array}$ & $\begin{array}{r}-0.01 \\
(0.90)\end{array}$ & 1 & & & & & \\
\hline (6) RD/sales & $\begin{array}{l}-0.24 \\
(0.01)\end{array}$ & $\begin{array}{l}-0.25 \\
(0.00)\end{array}$ & $\begin{array}{l}-0.33 \\
(0.00)\end{array}$ & $\begin{array}{l}-0.28 \\
(0.01)\end{array}$ & $\begin{array}{l}-0.20 \\
(0.02)\end{array}$ & 1 & & & & \\
\hline (7) Role Specifice Experience & $\begin{array}{r}0.06 \\
+(0.51)\end{array}$ & $\begin{array}{r}0.16 \\
(0.06)\end{array}$ & $\begin{array}{r}0.16 \\
(0.11)\end{array}$ & $\begin{array}{r}-0.05 \\
(0.69)\end{array}$ & $\begin{array}{r}0.05 \\
+(0.61)\end{array}$ & $\begin{array}{r}0.18 \\
(0.04)\end{array}$ & 1 & & & \\
\hline (8) Firm Specific Experience & $\begin{array}{l}-0.06 \\
(0.47)\end{array}$ & $\begin{array}{c}0.00 \\
(0.99)\end{array}$ & $\begin{array}{c}0.09 \\
(0.37)\end{array}$ & $\begin{array}{c}0.10 \\
(0.39)\end{array}$ & $\begin{array}{l}-0.13 \\
(0.13)\end{array}$ & $\begin{array}{l}-0.02 \\
(0.85)\end{array}$ & $\begin{array}{c}0.54 \\
(0.00)\end{array}$ & 1 & & \\
\hline (9) Firm Size & $\begin{array}{r}0.60 \\
+0.00)\end{array}$ & $\begin{array}{r}0.63 \\
(0.00)\end{array}$ & $\begin{array}{r}0.49 \\
(0.00)\end{array}$ & $\begin{array}{r}0.23 \\
-\quad(0.04)\end{array}$ & $\begin{array}{r}0.36 \\
(0.00)\end{array}$ & $\begin{array}{l}-0.48 \\
(0.00)\end{array}$ & $\begin{array}{r}0.05 \\
-\quad(0.55)\end{array}$ & $\begin{array}{l}0.03 \\
(0.72)\end{array}$ & 1 & \\
\hline (10) ROA & $\begin{array}{c}0.09 \\
(0.32)\end{array}$ & $\begin{array}{c}0.10 \\
(0.27)\end{array}$ & $\begin{array}{l}-0.22 \\
(0.03)\end{array}$ & $\begin{array}{c}0.11 \\
(0.32)\end{array}$ & $\begin{array}{c}-0.22 \\
(0.01)\end{array}$ & $\begin{array}{l}0.08 \\
(.38)\end{array}$ & $\begin{array}{l}-0.05 \\
(0.53)\end{array}$ & $\begin{array}{l}-0.09 \\
(0.31)\end{array}$ & $\begin{array}{l}0.06 \\
(0.52)\end{array}$ & 1 \\
\hline
\end{tabular}




\section{Univariate Analysis}

We first examine the possible roles of selected marketing assets - customer satisfaction (H1), branding strategy (H2), firm strategy $(\mathrm{H} 3)$, and role specific experience of marketing executives (H4) in explaining the compensation of marketing executives, respectively, with univariate analysis. In specific, we apply the difference in means test on the three compensation measures (total current compensation, salary, and bonus), respectively, for each marketing asset variable, using their respective median value to split the sample evenly where appropriate. We divide the sample according to the median of the customer satisfaction rating, innovation (RDSales), and role specific experience, respectively, reported in Table 1. We next calculate the average values of the three compensation variables for firms above and below the median split for each marketing asset variable. For the branding strategy, we compare the average values of the three compensation variables for the CMOs of firms adopting the corporate branding strategy versus otherwise.

Table 3 reports the univariate results of the difference in means test where the above and below median splits are represented as 'high' (above the median) and 'low' (below the median). Marketing executives affiliated with companies that have high satisfaction rating are compensated significantly more than their peers with low satisfaction rating, despite the choice of the compensation measure. This result supports our postulation (H1) that customer satisfaction has a positive impact on the compensation of marketing executives. The average current compensation $(\$ 633 \mathrm{~K})$ of CMOs of firms that achieve above-median customer satisfaction rating is economically and statistically higher than that for below-median firms $(\$ 358 \mathrm{~K})$.

Consistent with the postulation (H2) that the corporate branding strategy has a positive impact on marketing executive compensation, we find that companies adopting the corporate branding strategy $(\$ 518 \mathrm{~K})$ pay their marketing executives significantly more than companies adopting other branding strategies $(\$ 407 \mathrm{~K})$. This result holds across all three compensation measures. On the other hand, the univariate results reported in Table 3 do not lend much support for the possible impacts of firm's investment in innovation and marketing executive's experience, respectively, on the compensation variables. While both of these marketing assets have positive influence on compensation of marketing executives, the difference in means tests do not yield statistically significant results across the three measures.

Table 3: Univariate Results - Difference in Means Test

\begin{tabular}{|c|c|c|c|c|}
\hline & Satisfaction & Branding & RD/Sales & $\begin{array}{c}\text { Role Specific } \\
\text { Experience }\end{array}$ \\
\hline & High & Non-Corp & High & High \\
\hline $\begin{array}{l}\text { Total Current } \\
\text { Compensation }\end{array}$ & $\begin{array}{ll}\$ 633 & \$ 358 \\
t=5.221 & (.000)\end{array}$ & $\begin{array}{rr}\$ 518 & \$ 407 \\
t=2.370 & (.019)\end{array}$ & $\begin{array}{ll}\$ 523 & \$ 441 \\
t=1.640 & (.104)\end{array}$ & $\begin{array}{cc}\$ 483 & \$ 459 \\
t & =.436\end{array}$ \\
\hline Salary & $\begin{array}{lr}\$ 384 & \$ 279 \\
t=3.513 & (.001)\end{array}$ & $\begin{array}{rr}\$ 351 & \$ 290 \\
\mathrm{t}=2.402 & (.018)\end{array}$ & $\begin{array}{ll}\$ 347 & \$ 311 \\
\mathrm{t}=1.533 & (.128)\end{array}$ & $\begin{array}{ll}\$ 340 & \$ 308 \\
t=1.361 & (.176)\end{array}$ \\
\hline Bonus & $\begin{array}{ll}\$ 255 & \$ 105 \\
t=3.007 & (.004)\end{array}$ & $\begin{array}{rr}\$ 224 & \$ 123 \\
t=2.642 & (.010)\end{array}$ & $\begin{array}{ll}\$ 189 & \$ 164 \\
t=.580 & (.563)\end{array}$ & $\begin{array}{ll}\$ 217 & \$ 141 \\
t=1.845 & (.068)\end{array}$ \\
\hline
\end{tabular}

Dollars in 1,000 s

Table 4 reports the weighted least squares (WLS) regression results on the three compensation measures. The WLS regression resolves the heteroscedasticity problem, detected by the White (1980) test, using the firm size as the weight. Panel A presents the regression result of Model 1 with total current compensation as the dependent variable. The model explains $46 \%$ of the variation in total current compensation of marketing executives. All of the explanatory and control variables are statistically significant with expected signs, except for the branding strategy variable. The results indicate that intangible marketing assets such as customer satisfaction, innovation, and role 
specific experience of marketing executives have positive impacts on CMO total current compensation. Consistent with the findings in other executive compensation studies, the statistically significant coefficients for the control variables highlight the impacts of the scale effect and the wage compression effect on marketing executive compensation. The less significant effect of the profitability variable echoes the concern regarding the limitation of accounting based performance measure in explaining executive compensation (Mizik and Jacobson, 2007).

The results for Model 2 using CMO salary as the compensation variable are presented in Panel B. This model has an adjusted $\mathrm{R}^{2}$ of .400 with results parallel those of Model 1, i.e., customer satisfaction and role specific experiences continue to have statistically significant positive impacts on the compensation of marketing executives. However, innovation does not play a significant role in explaining CMO salary.

For Model 3 with CMO bonus as the dependent variable, the sample is smaller with 63 observations due to a quarter of sample CMOs do not have bonus data. Though this regression has a significant F-statistic of 3.67, it only explains $24 \%$ of the variation in CMO bonus. However, the significant positive impact of customer satisfaction on compensation of marketing executive persists in this regression.

Table 4: Regression Results

\begin{tabular}{|c|c|c|c|c|c|c|c|c|c|c|}
\hline & & \multicolumn{3}{|c|}{$\begin{array}{c}\text { Panel A } \\
\text { Total Current Compensation } \\
\end{array}$} & \multicolumn{3}{|c|}{$\begin{array}{l}\text { Panel B } \\
\text { Salary }\end{array}$} & \multicolumn{3}{|c|}{$\begin{array}{l}\text { Panel C } \\
\text { Bonus }\end{array}$} \\
\hline & Variable & $\begin{array}{l}\text { Mean } \\
\text { coeff }\end{array}$ & t-stat & Prob & $\begin{array}{l}\text { Mean } \\
\text { coeff }\end{array}$ & t-stat & Prob & $\begin{array}{l}\text { Mean } \\
\text { coeff }\end{array}$ & t-stat & Prob \\
\hline & Intercept & 1.58531 & 1.9 & 0.0618 & 3.6617 & 5.79 & $<.0001$ & -14.2456 & -2.70 & 0.0089 \\
\hline $\mathrm{H} 1:$ & Satisfaction & 0.04651 & 4.85 & $<.0001$ & 0.0176 & 2.41 & 0.0191 & 0.2170 & 3.57 & 0.0007 \\
\hline H2: & Branding & 0.0288 & 0.23 & 0.8182 & 0.0134 & 0.14 & 0.8883 & -0.2234 & -0.28 & 0.7780 \\
\hline H3: & RD/Sales & 4.1144 & 2.047 & 0.0455 & 1.5425 & 1.01 & 0.3175 & 4.3165 & 0.34 & 0.7360 \\
\hline H4: & Role Specific & 0.01558 & 2.06 & 0.0442 & 0.0242 & 4.20 & $<.0001$ & -0.0628 & -1.31 & 0.1955 \\
\hline Controls: & Firm Specific & -0.0126 & -2.16 & 0.0345 & -0.0113 & -2.56 & 0.0129 & -0.0427 & -1.16 & 0.2495 \\
\hline & LnNumEmpl & 0.28886 & 5.92 & $<.0001$ & 0.1752 & 4.73 & $<.0001$ & 0.9599 & 3.11 & 0.0029 \\
\hline & ROA & 0.01462 & 1.87 & 0.0663 & 0.0092 & 1.55 & 0.1255 & 0.0273 & 0.55 & 0.5830 \\
\hline & F-statistic & 11.40 & $<.0000$ & & 9.33 & $<.0000$ & & 3.67 & 0.0026 & \\
\hline & Adjusted $R^{2}$ & 0.455 & & & 0.400 & & & 0.239 & & \\
\hline & Total Obs. & 84 & & & 84 & & & 63 & & \\
\hline
\end{tabular}

In summary, both univariate and regression results consistently support our main hypothesis on a significant positive impact of customer satisfaction on all three compensation measures of marketing executives. This key result holds after we control for other determinants of executive compensation such as firm size, profitability, and wage compression. In addition, we find mixed support for the respective role of other selected marketing assets such as the role specific experience of marketing executives in the field, the investment in innovation and the branding strategy of the firm in the design of compensation package. For instance, the univariate results support the postulation that companies adopting a corporate branding strategy place heavy emphasis on the role of marketing executives that is reflected in their compensation. But after controlling for other determinants of executive compensation, the significance of the branding strategy on compensation measures vanishes.

Our results support the postulation that intangible marketing assets such as customer satisfaction, which is known to contribute to financial performance of a firm, should be part of the compensation package for the executive directly responsible for the outcome, namely, Chief Marketing Office (CMO). Our study is the first to document a positive link between customer satisfaction and the compensation of senior marketing executives. 
Along with the finding of the positive role of customer satisfaction on the CEO bonus (O'Connell and Sullivan, 2010), there is growing evidence calling for the inclusion of nonfinancial performance measure in the design of executive compensation package.

\section{CONCLUSION}

The purpose of this research is to address the question: Does the intangible asset of customer satisfaction impact CMO compensation? Our univariate and regression results show a persistent significant and positive relationship between customer satisfaction and CMO total current compensation, salary, and bonus, even controlling for other determinants of executive compensation. Our findings suggest that senior marketing executives are compensated for the favorable outcome of their primary responsibilities, i.e., high customer satisfaction rating, which is known to have a positive impact on the financial performance and valuation of a firm. In summary, we answer a call in the marketing and management literature for studying the role of intangible marketing assets in determining executive compensation. Our research adds to the body of empirical research that calls for and supports the inclusion of nonfinancial performance measure in the design of executive compensation.

Our study offers two managerial implications: (1) Our findings support the importance of including nonfinancial performance measures in CMO compensation package. It follows that compensation schemes for the CMO should balance accounting-based measures of performance with marketing based measures for which the CMO is primarily responsible. Companies interested in hiring their senior marketing executives should find our findings useful in designing compensation packages. Likewise, companies that have experienced CMO turnover might review how their CMO performance is assessed and adjust compensation packages as well. (2) The positive impact of customer satisfaction on CMO compensation echoes its positive impacts on CEO bonus and on the financial performance and valuation of the firm. The top management team, especially marketing executives, could use our findings to leverage investment in intangible marketing assets.

\section{AUTHOR INFORMATION}

Hei-Wai Lee, (Ph.D., The University of Illinois at Urbana-Champaign) is a Professor of Finance at The University of Michigan-Dearborn. His current research interests include seasoned security issuance and IPOs, information content of analysts' coverage, cross-listing of foreign firms, insider trading, managerial compensation, and capital market research. He has published over 30 articles in Financial Management, Financial Review, Journal of Business Finance and Accounting, Journal of Business Research, Journal of Financial Research, and Journal of Applied Business Research, etc. E-mail: heiwail@umd.umich.edu

Crystal J. Scott (Ph.D., The Pennsylvania State University) is an Assistant Professor of Marketing at The University of Michigan-Dearborn. Her research interests include marketing leadership, small business marketing, and the cross-functional integration. Her work has appeared in Journal of Marketing for Higher Education, Journal of Modeling in Management, and Journal of Marketing Research. E-mail: cjscott@umd.umich.edu (Corresponding author)

\section{REFERENCES}

1. Anderson E.W., C. Fornell, and S.K. Mazvancheryl (2004), "Customer Satisfaction and Shareholder Value," Journal of Marketing, v. 68(4), pp.172-185.

2. Balkin, D.B., G.D. Markman and L.R. Gomez-Mejia (2000). "Is CEO Pay in High-Technology Firms Related to Innovation?", The Academy of Management Journal, 43(6), pp. 1118-1129.

3. Balsam S, Fernando GD, Tripathy A. (2011) "The impact of firm strategy of performance measures used in executive compensation", Journal of Business Research, 64: pp.187-193.

4. Boyd D.E., Chandy R., and Cunha M. Jr. (2010) "When do Chief Marketing Officers impact value? A customer power explanation", Journal of Marketing Research, 47(6): pp.1162-1176.

5. Devers, C., A.A. Cannella Jr., G.P. Reilly, and M.E. Yoder (2007), "Executive Compensation: A Multidisciplinary Review of Recent Developments", Journal of Management, 33, pp.1016-1072. 
6. Dikolli S.S. and I. Vaysman (2006) "Contracting on the Stock Price and Forward-Looking Performance Measures," European Accounting Review, 15(4), pp.445-464.

7. Fornell, C., M.D. Johnson, E.W. Anderson, and J. Cha (1996), "The American Customer Satisfaction Index: Nature, Purpose, and Findings," vol. 58 (October), pp.7-18.

8. Fornell C, S. Mithas, F.V. Morgeson III, and M.S. Krishnan (2006), "Customer Satisfaction and Stock Prices: High Returns, Low Risk". Journal of Marketing, 70: 3-14.

9. Goergen M. and L. Renneboog (2011), “Managerial Compensation”, Journal of Corporate Finance, 17 (4): pp. 1068-1077.

10. Gruca, T. and L.L. Rego (2005), "Customer Satisfaction, Cash Flow, and Shareholder Value”. Journal of Marketing: Vol. 69, No. 3, pp. 1-130.

11. Hambrick D.C. and Finkelstein S. (1995), "The effects of ownership structure on conditions at the top: the case of CEO pay", Strategic Management Journal 16(3): pp.175-193.

12. Homburg, C., J.P. Workman, Jr. and Harley Krohmer (1999), "Marketing's Influence within the Firm", The Journal of Marketing, 63(2) pp. 1-17.

13. Jensen M. and K. Murphy (1990), "Performance pay and top management incentives", Journal of Political Economy, 98: pp.225-264.

14. Laforet, S. and J. Saunders (1994), "Managing Brand Portfolios: How the Leaders Do It", Journal of Advertising Research, 34 (September), pp.64-76.

15. Luo, X. and C. Homburg (2007), "Neglected Outcomes of Customer Satisfaction," Journal of Marketing, 71(April), pp.133-149.

16. Luo, X., C. Homburg, and J. Wieseke (2010), “Customer Satisfaction, Analyst Stock Recommendations, and Firm Value", Journal of Marketing Research, 47, pp.1041-1058.

17. Mittal, V., Anderson, E.W., Sayrak, A., and Tadikamalla (2005), "Dual Emphasis and the Long-Term Financial Impact of Customer Satisfaction", Marketing Science, 24(4), pp.544-555.

18. Mizik, N. and R. Jacobson ( 2007), "Myopic Marketing Management: Evidence of the Phenomenon and Its Long-Term Performance Consequences in the SEO Context," Marketing Science, INFORMS, 26(3), pp.361-379.

19. Montemayor, E.F. (1996), "Congruence between pay policy and competitive strategy in high-performing firms". Journal of Management, 22(6), pp.889-908.

20. Nath P. and V. Mahajan (2008). Chief Marketing Officers: A Study of Their Presence in Firms' Top Management Teams. Journal of Marketing, Vol. 72, No. 1, pp. 65-81.

21. Nath, P. and V. Mahajan (2011). Marketing in the C-Suite: A Study of Chief Marketing Officer Power in Firms' Top Management Teams. Journal of Marketing: Vol. 75, No. 1, pp. 60-77.

22. O'Connell, V. and D. O'Sullivan (2010), “The Impact of Customer Satisfaction on CEO Bonuses” Journal of the Academy of Marketing Science, pp.1-18. Doi: 10.1007/s11747-010-0218-1

23. Srinivasan S., and D.M. Hansens (2009), "Marketing and firm value: Metrics, methods, findings, and future directions." Journal of Marketing Research, 46, pp.293-312.

24. Srivastava R.K., T.A. Shervani, and L. Fahey (1998), "Market-based assets and shareholder value: a framework for analysis". Journal of Marketing 62: pp.2-18.

25. Stewart, D.W. (2009), "Marketing accountability: Linking marketing actions to financial results", Journal of Business Research, 62, pp.636-643.

26. Tosi H.L., W. Werner, J.P. Katz, and L.R. Gomez-Mejia, L.R. (2000), "How much does performance matter? A meta-analysis of CEO pay studies". Journal of Management, 26(2), pp.301-339.

27. White, H. (1980), "Heteroskedasticity-Consistent Covariance Matrix Estimator and a Direct Test for Heteroskedasticity." Econometrica, 48(4), pp.817-83. 